\title{
Sistem Pakar Diagnosis Penyakit Pada Tanaman Pepaya Menggunakan Metode Backward Chaining Berbasis Web
}

\author{
Noviani \\ Politeknik Pertanian Negeri \\ Samarinda Teknologi Rekayasa \\ Perangkat Lunak Manajemen \\ Pertanian \\ Samarinda, Kalimantan Timur \\ aninovi018@gmail.com
}

\author{
Dwi Arief Prambudi \\ Teknologi Rekayasa Perangkat \\ Lunak \\ Politeknik Pertanian Negeri \\ Samarinda Manajemen Pertanian \\ Samarinda, Kalimantan Timur \\ prambudiariefdwi@gmail.com
}

\author{
Fadli Mulyadi \\ Pengelolaan Perkebunan \\ Politeknik Pertanian Negeri \\ Samarinda Manajemen Pertanian \\ Samarinda, Kalimantan Timur \\ fadli.mulyadi@gmail.com
}

\begin{abstract}
Abstrak - Penelitian sistem pakar diagnosis penyakit pada tanaman pepaya ini bertujuan untuk merancang dan membangun suatu sistem untuk mediagnosa penyakit tanaman papaya. Model inferensi yang digunakan dalam pembuatan sistem pakar ini adalah penalaran mundur (Backward Chaining). Diharapkan dalam pembuatan sistem pakar dengan menggunakan metode Backward Chaining dalam penelitian ini dapat membantu petani dalam melakukan diagnosa awal terhadap suatu penyakit tanaman pepaya dan memberikan solusi untuk mengatasi penyakit pada tanaman pepaya tersebut. Hasil dari pembuatan Sistem Pakar ini mampu membuktikan kebenaran suatu penyakit papaya dan memberi solusi dalam menangani penyakit pepaya tersebut. Pembuatan aplikasi sistem pakar diagnosa penyakit pada tanaman pepaya berbasis web menggunakan bahasa pemograman PHP(Hypertext Preprocessor) dan Database MY Structured Query Language (MYSQL).
\end{abstract}

Kata Kunci-backward chaining, penyakit pepaya.

\section{PENDAHULUAN}

Pepaya memiliki kandungan unsur gizi lengkap, termaksuk vitamin A yang jarang terdapat pada buahbuahan lain. Disamping itu, buah pepaya juga merupakan sumber enzim papain dan pektin yang bernilai ekonomi sangat tinggi.

Pepaya merupakan tanaman yang banyak dibudidayakan di Indonesia. Masyarakat Indonesia biasa menanam tanaman ini di pekarangan atau di sawah. Namun, pada umumnya masyarakat menanam tanaman ini hanya sebatas digunakan untuk memenuhi kebutuhan sayur atau buah dalam rumah tangga.

Kompleknya mengandung senyawa yang terkandung dalam biji menjadikan biji papaya sebagai bahan yang dapat dimanfaatkan menjadi bahan olahan yang dapat di komsumsi dan memberikan manfaat bagi kesehatan manusia. Menurut (Agustina, 2013), biji papaya dapat di manfaatkan sebagai jus yang berkhasiat menurunkan kadar kolestrol tubuh dan sebagainya antioksida melalui zat fitokimia yang dikandungnya yaitu meliputiflavoid, saponin, dan tannin.
Dibalik kelebihan pepaya harga perbuahanya mahal dan daya busuk buahnya sangat lama. Masalah sekarang yang dihadapi adalah sering terserang hama dan penyakit, sehinga membuat tanaman tumbuh tidak sempurna. Kuranganya pengetahuan sehinga perlu dibuat sistem pakar untuk membantu para pembudidaya.

Dalam hal ini sistem pakar dihadirkan sebagai alternatif kedua dalam memecahkan permasalahan setelah seorang expert. Sistem pakar merupakan suatu program komputer cerdas yang menggunakan knowledge (pengetahuan) dan prosedur inferensi untuk menyelesaikan masalah yang cukup sulit sehingga membutuhkan seorang ahli untuk menyelesaikannya (Feigenbaum dan Buchanan, 1993). Suatu sistem pakar adalah suatu sistem komputer yang menyamai (emulates) kemampuan pengambilan keputusan dari seorang pakar. Istilah emulates berarti bahwa sistem pakar diharapkan dapat bekerja dalam semua hal seperti seorang pakar. Sistem pakar dibangun berdasarkan konsep-konsep yang dimiliki oleh seorang pakar. Dengan Sistem Pakar maka dapat membantu dalam memberikan solusi dari masalah yang ada setelah seorang pakar. Maka dalam hal ini penyusun mengusulkan penelitian untuk membangun sebuah aplikasi yang berjudul "Sistem Pakar Diagnosis Penyakit Pada Tanaman Pepaya Menggunakan Metode Backward Chaining Berbasis Web".

Berdasarkan latar belakang masalah di atas maka dapat diambil suatu perumusan masalah yaitu bagaimana merancang suatu aplikasi sistem pakar untuk mendiagnosis penyakit pada tanaman pepaya menggunakan Backward Chaining berbasis web untuk memudahkan informasi petani yang membutuhkan.

Mengingat masalah diatas terlalu luas maka, dalam penelitian ini peneliti akan membatasi masalah yang akan diteliti. Batasan masalah dari penelitian ini dalam pembahasan ini penulis hanya membatasi menggunakan teknik inferensi runut mundur (Backward Chaining) dan pendekatan berbasis aturan (rule base reasoning).

Tujuan penelitian dan hasil yang diharapkan dari perumusan diatas adalah sebagai berikut :

1. Membuat suatu aplikasi pengembangan sistem pakar berbasis web.

2. Mengetahui jenis penyakit pada tanaman pepaya dengan menggunakan metode Backward Chaining. . 


\section{TINJAUAN PUSTAKA}

\section{Kajian Ilmiah}

Beberapa literatur yang digunakan sebagai pedoman dan acuan dalam Tugas Akhir ini antara lain :

1. Penelitian yang dilakukan oleh Aris Widyanto (2009) yang berjudul Sistem Pakar Untuk Mendiagnosa Hama dan Penyakit Tanaman Pepaya Mengunakan Metode Forward Chaining. Program Studi Teknik Informatika, Universitas Dian Nuswantoro. Sistem ini membahas tentang mendiagnosa hama dan penyakit pada tanaman dengan metode yang digunakan yaitu metode forwand chaining. Penelitian ini menggunakan bahasa pemprograman Microsoft Visual Basic 6.0.

2. Penelitian yang dilakukan oleh Honggowibowo (2009) yang berjudul Sistem Pakar Diagnosa Penyakit Tanaman Padi Berbasis Web Dengan Forward Chaining Dan Backward Chaining Jurusan Teknik Informatika. Sistem ini membahas tentang penyakit tanaman padi. Perancangan sistem ini menggunakan bahasa pemograman Hypertext PreProcessor (PHP) dan menggunakan My Structured Query Language (MySQL).

3. Penelitian yang dilakukan oleh Afit Nadhar Pratitis (2010) yang berjudul Sistem Pakar Diagnosa Penyakit Dan Hama Pada Tanaman Pepaya California Di Dusun Kethitang-Rawalo. STMIK Amikom Purwokerto. Sistem ini membahas tentang merancang dan membangun sistem pakar diagnosa penyakit dan hama tanaman papaya California dengan metode yang digunakan yaitu metode forwand chaining. Penelitian ini menggunakan bahasa pemrograman Adobe Dreamweaver CS5 dan XAMPP-Win32-1.7.

4. Penelitian yang dilakukan oleh Bella Anita Maulina (2016) yang berjudul Sistem Pakar Diagnosis Hama Dan Penyakit Tanaman Kacang Tanah Berbasis Deskop Dengan Metode Backward Chaining. Program Studi Teknik Informatika, Fakultas Teknik Universitas Suryakancana Cianjur. Sistem ini membahas tentang pengetahuan petani akan hama dan penyakit mengenai tanaman kacang tanah metode yang digunakan yaitu metode Backward Chaining. Penelitian ini menggunakan bahasa pemrograman Borland Delphi 7.

5. Penelitian yang dilakukan oleh Ade Eka Novita Pratiwi (2018) yang berjudul Sistem Penyakit Pada Tanaman Cabai Merah Dengan Metode Backward Chaining (Studi Kasus Cabai Merah Desa Grobongan Kabupaten Medium). Program Studi Teknik Informatika, Universitas Sebelas Maret. Sistem ini membahas tentang membangun suatu sistem untuk mediagnosa penyakit tanaman cabai merah dengan metode yang digunakan yaitu metode Backward Chaining. Penelitian ini menggunakan bahasa pemrograman Hypertext PreProcessor (PHP) dan menggunakan My Structured Query Language (MySQL).
Berdasarkan uraian dari penelitian dan jurnal sebelumnya, sistem yang akan dibuat memiliki kelebihan yakni objek yang akan diangkat berbeda dengan penelitian sebelumnya yaitu penyakit pada tanaman pepaya.

\section{Tanaman Pepaya}

Nama umum pepaya didunia adalah "PawPaw", namun diberbagai negara memiliki nama yang beragam.Misalnya di Malaysia disebut "Betik", di Tamil dinamakan "Pappali". Di cina dikenal dengan "Pohon Melon" (Tree-melon), dan di indonesia populer dengan nama "pepaya" (Rakmana, 1995). Jenis pepaya yang umum yaitu pepaya california, pepaya bangkok, pepaya hawai, pepaya cibinong, pepaya gunung.

Pepaya Carica pepaya $L$ merupakan tanaman yang berasal dari Amerika Tengah. Pepaya dapat tumbuh dengan baik di daerah yang beriklim tropis. Tanaman pepaya oleh para pedagang Spanyol disebarluaskan ke berbagai penjuru dunia. Negara penghasil pepaya antara lain Costa Rica, Republik Dominika, Puerto Riko, dan lain-lain, (Warisno, 2003).

Bedasarkan klasifikasi taksonomi kedudukan tanaman papaya dalam sistematik (taksonomi) tumbuhan diklasifikasi sebagai berikut:

$\begin{array}{ll}\text { Kingdom } & : \text { Plantae (Tumbuh-Tumbuhan) } \\ \text { Devisi } & \text { : Spermatophyta } \text { (Tumbuhan berbiji) } \\ \text { Kelas } & : \text { Angiosperma (Biji tertutup) } \\ \text { Sub-kelas } & : \text { Dicotyledonae (Biji Berkeping } \\ \text { Dua) } & : \text { Caricales } \\ \text { Ordo } & : \text { Caricaceae } \\ \text { Famili } & : \text { Carica papaya } L\end{array}$

Spesie lain yang sering tumbuh di daearah-daerah daratan tinggi (pegunungan) adalah $C$. cauliflora. Ciriciri tanaman pepaya pepaya ini adalah buahnya kecilkecil, licin, tahan terhadap serangan penyakit akar ataupun virus, tetapi tidak bisa dimakan.

\section{Sistem Pakar}

Sistem pakar merupakan sistem yang berusaha mengadopsi pengetahuan manusia ke komputer, agar komputer dapat menyelesaiakan masalah seperti yang biasa dilakukan oleh para ahli. Sistem pakar biasanya digunakan untuk melakukan interprestasi dan analisa, diagnosa, dan membantu pengambilan keputusan, (Oktaviani, 2012).

Sistem pakar (expert system) adalah sistem yang berusaha mengapdosi pengetahuan manusia ke komputer, agar komputer dapat menyelesaikan masalah seperti yang biasa dilakukan oleh para ahli. Sistem pakar yang baik dirancang agar dapat menyelesaikan suatu permasalahan tertentu dengan meniru kerja dari para ahli. Dengan sistem pakar, orang awam pun dapat menyelesaikan masalah yang cukup rumit yang sebenarnya hanya dapat diselesaikan dengan bantuan para ahli. Bagi para ahli, sistem pakar juga akan membantu aktivitasnya sebagai asisten yang sangat berpengalaman, (Kusumadewi, 2003). 
Sistem pakar adalah salah satu cabang dari AI yang membuat penggunaan secara luas knowledge yang khusus untuk penyelesaian masalah tingkat manusia yang pakar. Seorang pakar adalah orang yang mempunyai keahlian dalam bidang tertentu, yaitu pakar yang mempunyai knowledge atau kemampuan khusus yang orang lain tidak mengetahui atau mampu dalam bidang yang dimilikinya. Ketika sistem pakar dikembangkan pertama kali sekitar tahun 70-an, sistem pakar hanya berisi knowledge yang eksklusif. Namun demikian sekarang ini istilah sistem pakar sudah digunakan untuk berbagai macam sistem yang menggunakan teknologi sistem pakar itu. Teknologi sistem pakar ini meliputi bahasa sistem pakar, program dan perangkat keras yang dirancang untuk membantu pengembangan dan pembuatan sistem pakar.

\section{Metode Backward Chaining}

Backward Chaining menggunakan pendekatan goal-driven, dimulai dari harapan apa yang akan terjadi (hipotesis) dan kemudian mencari bukti yang mendukung (atau berlawanan) dengan harapan kita. Sering hal ini memerlukan perumusan dan pengujian hipotesis sementara. Jika suatu aplikasi menghasilkan tree yang sempit dan cukup dalam, maka gunakan Backward Chaining.

Menurut (Muhammad Dahria, 2011) Runut balik (Backward Chaining) merupakan strategi pencarian yang arahnya kebalikan dari runut maju (Forward Chaining). Proses pencarian dimulai dari tujuan, yaitu kesimpulan yang menjadi solusi permasalahan yang dihadapi. Mesin inferensi mencari kaidah-kaidah dalam basis pengetahuan yang kesimpulannya merupakan solusi yang ingin dicapai, kemudian dari kaidah-kaidah yang diperoleh, masing-masing kesimpulan dirunut balik jalur yang mengarah ke kesimpulann tersebut.

Backward Chaining adalah suatu alasan berkebalikan dengan hipotesis, dimana hipotesis dihasilkan setelah mengumpulkan fakta-fakta yang sudah ada secara lengkap lalu diambil kesimpulan (conclusion) atau hipotesisnya sedangkan Backward Chaining akan memperkirakan potensial kesimpulan (conclusion) yang mungkin terjadi atau terbukti, karena adanya fakta yang mendukung hipotesis tersebut, (Jogiyanto HM, 2011).

\section{PHP (Hypertext Preprocessor)}

PHP (Hypertext Preprocessor), merupakan bahasa pemrograman pada sisi server yang memperbolehkan programmer menyisipkan perintah-perintah perangkat lunak web server (Apache, IIS, atau apapun) akan dieksekusi sebelum perintah itu dikirim oleh halaman ke browser yang me-request-nya, contohnya adalah bagaimana memungkinkannya memasukkan tanggal sekarang pada sebuah halaman web setiap kali tampilan tanggal dibutuhkan, (Herny Februariyanti, 2012). Sesuai dengan fungsinya yang berjalan di sisi server maka PHP adalah bahasa pemrograman yang digunakan untuk membangun teknologi web application. (Kevin Yank, 2002) PHP telah menjadi bahasa scripting untuk keperluan umum yang pada awalnya hanya digunakan untuk pembangunan web yang menghasilkan halaman web dinamis. Untuk tujuan ini, kode PHP tertanam ke dalam dokumen sumber HTML dan diinterpretasikan oleh server web dengan modul PHP prosesor, yang menghasilkan dokumen halaman web. Sebagai bahasa pemrograman untuk tujuan umum, kode PHP diproses oleh aplikasi penerjemah dalam modus baris-baris perintah modus dan melakukan operasi yang diinginkan sesuai sistem operasi untuk menghasilkan keluaran program dichannel output standar. Hal ini juga dapat berfungsi sebagai aplikasi grafis. PHP tersedia sebagai prosesor untuk server web yang paling modern dan sebagai penerjemah mandiri pada sebagian besar system operasi dan komputer platform.

\section{Database My Structured Query Language (MYSQL)}

"MySQL adalah sebuah basis data yang mengandung satu atau jumlah tabel. Tabel terdiri atas sejumlah baris dan setiap baris mengandung satu atau sejumlah tabel. Tabel terdiri atas sejumlah baris dan setiap baris mengandung satu atau sejumlah tabel", (Kustiyahningsih, 2011).

MySQL adalah database server open source yang cukup popular keberadaannya. Dengan berbagai keunggulan yang dimiliki, membuat software database ini banyak digunakan oleh praktisi untuk membangun suatu project. Adanya fasilitas API (Application Programming Interface yang dimiliki oleh MySQL, memungkinkan bermacam-macam aplikasi komputer yang ditulis dengan berbagai bahasa pemrograman dapat mengakses basis data MySQL, (Wahana Komputer, 2010).

MySQL (My Structured Query Language) adalah: “ Suatu sistem basis data relation atau Relational Database managemnt System (RDBMS) yang mampu bekerja secara cepat dan mudah digunakan MySQL juga merupakan program pengakses database yang bersifat jaringan, sehingga sapat digunakan untuk aplikasi multi user (banyak pengguna). MySQL didistribusikan gratis dibawah lisensi GPL (General Public License). Dimana setiap program bebas menggunakan MySQL namun tidak bisa dijadikan produk turunan yang dijadikan closed source atau komersial", (Adi Nugroho, 2011).

\section{Website}

Website adalah: "Web dapat diartikan sebagai kumpulan halaman yang menampilkan informasi data teks, data gambar, data animasi, suara, video dan gabungan dari semuanya, baik yang bersifat statis maupun dinamis yang membentuk satu rangkaian bangunan yang saling terkait, dimana masing-masing dihubungkan dengan jaringan-jaringan halaman (hyperlink)", (Agus Hariyanto, 2015).

Web adalah : "Sekumpulan halaman yang terdiri dari beberapa halaman yang berisi informasi dalam bentuk data digital baik berupa text, gambar, video, audio, dan animasi lainnya yang disediakan melalui jalur koneksi internet”, (Rohi Abdulloh, 2015).

Berdasarkan uraian, penulis menyimpulkan bahwa web adalah Sebuah software yang berfungsi untuk menampilkan dokumen-dokumen pada suatu web yang 
membuat pengguna dapat mengakses internet melalui software yang terkoneksi dengan internet.

\section{XАMPP}

XAMPP adalah sebuah software web server apache yang didalamnya sudah tersedia database server MySQL dan dapat mendukung pemrograman PHP. XAMPP merupakan software yang mudah digunakan, gratis dan mendukung instalasi di Linux dan Windows. Keuntungan lainnya adalah cuma menginstal satu kali sudah tersedia Apache Web Server, MySQL Database Server, PHP Support (PHP 4 dan PHP 5) dan beberapa module lainnya, (Herny Februariyanti, 2012).

\section{Entity Relationship Diagram (ERD)}

Entity Relationship Diagram (ERD) adalah sekumpulan cara atau peralatan untuk mendeskripsikan data-data atau objek-objek yang dibuat berdasarkan dan berasal dari dunia nyata yang disebut entitas (entity) serta hubungan (relationship) antar entitas-entitas tersebut dengan menggunakan beberapa notasi. (Doro \& Stevalin).

ERD (Entity Relationship Diagram) adalah model teknik pendekatan yang menyatakan atau menggambarkan hubungan suatu model. Didalam hubungan ini tersebut dinyatakan yang utama dari ERD adalah menunjukan objek data (Entity) dan hubungan (Relationship), yang ada pada Entity berikutnya.

"Entity Relationship Diagram (ERD) adalah alat pemodelan data utama dan akan mambantu mengorganisasi data dalam suatu proyek ke dalam entitas-entitas dan menentukan hubungan antar entitas". Proses memungkinkan analis menghasilkan struktur basis data dapat disimpan dan diambil secara efisien, (Simarmata, 2010).

\section{Black Box Testing}

Black Box adalah merupakan pengujian yang berfokus pada spesifikasi fungsional dari perangkat lunak, tester dapat mendefinisikan kumpulan kondisi input dan melakukan pengetesan pada spesifikasi fungsional program. Black Box berfokus pada spesifikasi fungsional dari perangkat lunak, (M.Sidi Mustaqbal, 2015). Pengertian lainnya dari Black Box Testing adalah pengujian yang dilakukan hanya mengamati hasil eksekusi melalui data uji dan cek fungsional perangkat lunak. Jadi dianalogikan seperti kita melihat suatu koatak hitam, kit hanya bisa melihat penampilan luarnya saja, tanpa tau ada apa dibalik bungkus hitam nya. Sama seperti pengujian black box, mengevaluasi hanya dari tampilan luarnya (interface nya), fungsionalitasnya. tanpa mengetahui apa sesungguhnya yang terjadi dalam proses detilnya (hanya mengetahui input dan output).

\section{METODE PENELITIAN}

1. Alat

a. Perangkat Keras

1) Laptop (Ram 4GB Type 64 bit)

2) Akses Internet

b. Perangkat Lunak

1) Xampp

2) Subline Text 3

3) Browser google/mozila

4) Bootstrap/CSS

5) Mysql (My Structured Query Language)

Data penyakit tanaman jagung. Data tersebut ditunjukkan pada Tabel 1.

Tabel 1. Data penyakit pepaya

\begin{tabular}{|c|c|c|c|}
\hline No & Kode & $\begin{array}{c}\text { Nama } \\
\text { Penyakit }\end{array}$ & Penanggulangan \\
\hline 1. & P1 & $\begin{array}{l}\text { Busuk } \\
\text { Akar dan } \\
\text { Pangkal } \\
\text { Batang }\end{array}$ & $\begin{array}{l}\text { Penyakit ini ialah busuk akar } \\
\text { dan pangkal batang pepaya } \\
\text { dapat dilakukan dengan } \\
\text { perbaikan drainase tanah, } \\
\text { membongkar(mencabut) } \\
\text { tanaman yang sakit agar } \\
\text { tidak menjadi sumber } \\
\text { penularan, mengadakan } \\
\text { pergiliran (rotasi) tanaman, } \\
\text { dan disemprot (dikocor) } \\
\text { dengan fungisida yang } \\
\text { efektif seperti Dithane M-45 } \\
0,1 \%-0,2 \% \text {. }\end{array}$ \\
\hline 2. & $\mathrm{P} 2$ & $\begin{array}{l}\text { Penyakit } \\
\text { Tepung } \\
\text { Layu }\end{array}$ & $\begin{array}{l}\text { Penyakit ini dapat di lakukan } \\
\text { dengan cara fungsida yang } \\
\text { efektif seperti Dithane M-45 } \\
0,1 \%-0,2 \% \text {. }\end{array}$ \\
\hline
\end{tabular}

3. P3 Penyakit Dengan mengusahakan agar Busuk buah tidak luka atau memar Buah sewaktu masih dikebun Antraknosa maupun selepas panen, membersihkan sisa-sisa tanaman sakit di sekitar kebun, memperjarang jarak tanaman agar keadaan sekitar kebun tidak terlalu lembab.

4 P4 Penyakit Menggunakan benih atau Mosaik bibit pepaya yang bebas virus, dan bila serangan sudah terjadi sebaiknya pohon yang sakit segera dibongkar.

5 P5 Bercak Cincin
Menggunakan benih atau bibit yang bebas virus, dan membongkar tanaman yang sakit agar tidak menular. 
Tabel 2. Data penyakit pepaya

\begin{tabular}{ccl}
\hline No & Kode & \multicolumn{1}{c}{ Gejala Penyakit } \\
\hline 1. & G1 & $\begin{array}{l}\text { mula-mula daun bagian bawah layu. } \\
\text { menguning dan tangkai daunnya } \\
\text { menguning. }\end{array}$ \\
G & G3 & $\begin{array}{l}\text { Lambat-laun gejala yang sama akan } \\
\text { merembet ke bagian daun-daun muda yang } \\
\text { diikuti dengan makin mengecil ukuran } \\
\text { daun. }\end{array}$ \\
bagian pangkal batang dibongkar (digali) \\
27
\end{tabular}

Tabel 3. Data pembentukan rule

\begin{tabular}{|c|c|c|}
\hline Rule & If & Then \\
\hline R1 & G1,G2,G3,G4,G12 & P1 \\
\hline R2 & G5,G6,G7,G8,G9 & P2 \\
\hline R3 & G10,G11,G13, G14 & P3 \\
\hline R4 & G15,G16,G17,G18 G19,G20,G21, & P4 \\
\hline R5 & G22,G23,G24, & P5 \\
\hline R6 & G25,G26,G27,G28,G29 & P6 \\
\hline
\end{tabular}

$\begin{aligned} \text { Keterangan: G1-G29 } & =\text { Gejala } \\ \text { P1-P6 } & =\text { Penyakit }\end{aligned}$

\section{Prosedur Penelitian}

Berikut ini tampilan langkah-lngkah metode penelitian pada gambar 1 .

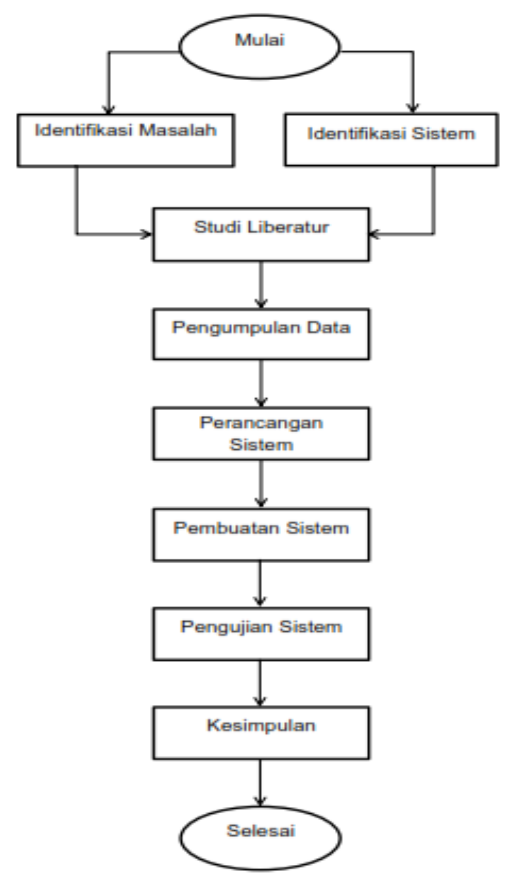

Gambar 1. Langkah-langkah Metode Penelitian

\section{Analisis Perancangan Sistem}

Dalam pengembangan perancangan sistem yang digunakan adalah data Flow Diagram (DFD), Entity Relationship Diagram (ERD). Berikut ini merupakan tampilan Data Flow Diagram Pada Gambar 2

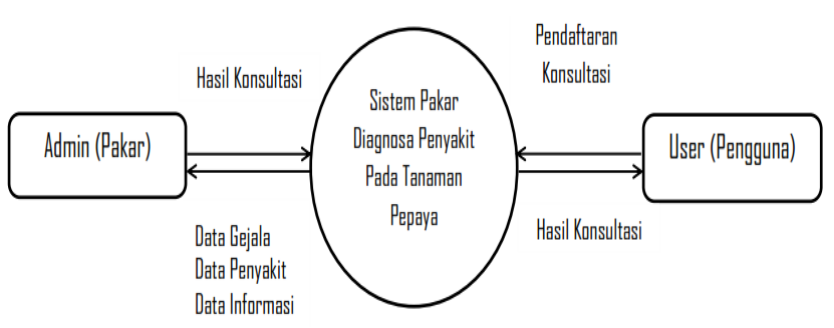

Gambar 2. DFD Level 0

ERD digunakan untuk menggambarkan mengenai berelasinya antar entitas. Pada Gambar 14 dibawah merupakan ERD Sistem Pakar Diagnosis Penyakit Pada Tanaman Pepaya Dengan Metode Backward Chaining Berbasis Web ini. Dimana terdapat 5 entitas yang 
meliputi user, Penyakit, Gejala, Informasi, Hasil Konsultasi.

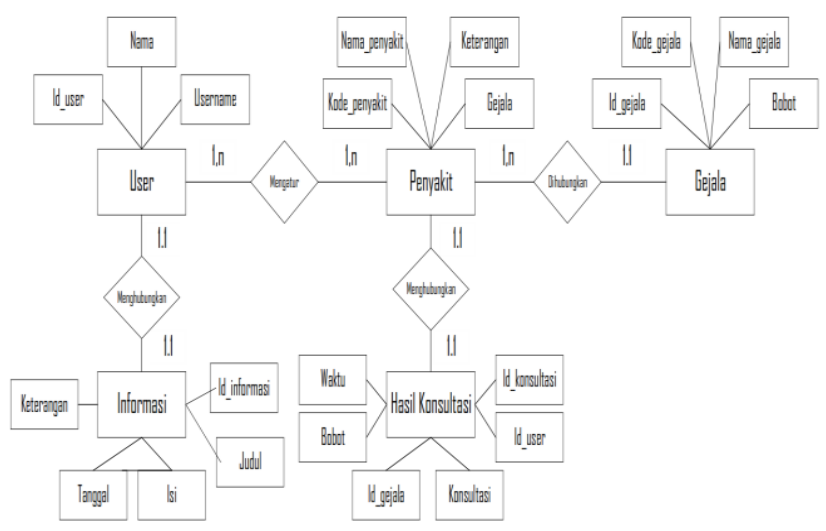

Gambar 3. ERD (Entitty Relaionship Diagram)

\section{HASIL DAN PEMBAHASAN}

\section{Hasil}

Berikut ini merupakan tampilan hasil dan pembahasan dari aplikasi Sistem Pakar Diagnosa Penyakit Pepaya Dengan Metode Backward Chaining Berbasis Web. Aplikasi dibuat untuk mempermuda para petani pepaya untuk mengecek penyakit pepaya.

\section{1) Halaman Utama}

Tampilan awal dari halaman home ketika pertama kali memasuki aplikasi sistem pakar ini. Pada halaman ini user langsung dapat konsultasi untuk dilakukan identifikasi jenis penyakit dari ciri yang terlihat pada papaya.

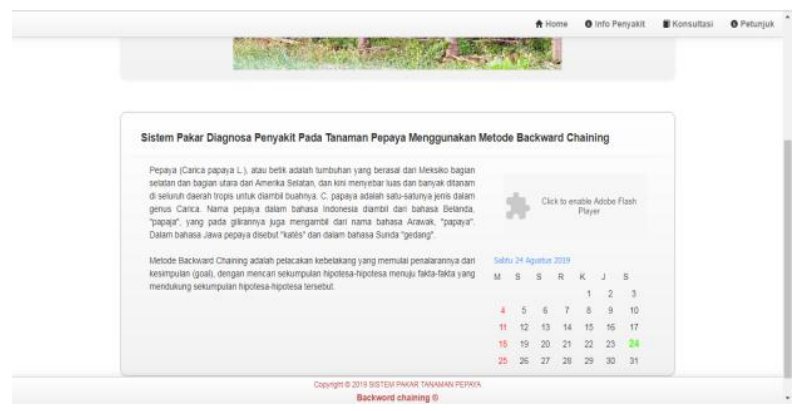

Gambar 4. Halaman Utama

2) Menu Info Penyakit

Pada menu ini terdapat data data info penyakit pepaya dimana dalam tersebut bisa mengetahui data penyababnya.

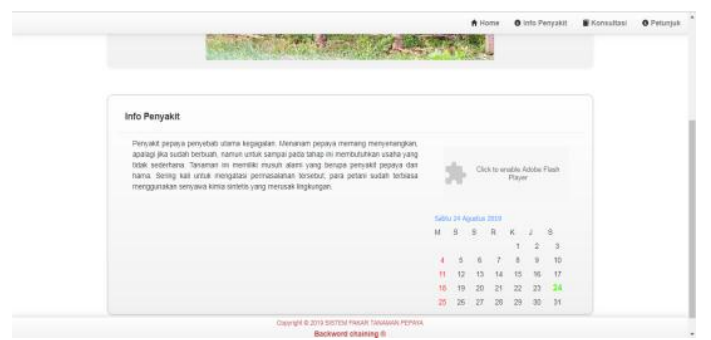

Gambar 5. Halaman Info Penyakit

\section{3) Menu Konsultasi}

Pada menu pengguna terlebih dahulu mengisi data yaitu nama, jenis kelamin, alamat dan nomor telpon dan selanjutnya terdapat checklist nama gejala penyakit papaya anda yang dialamin lalu hasilnya akan muncul.

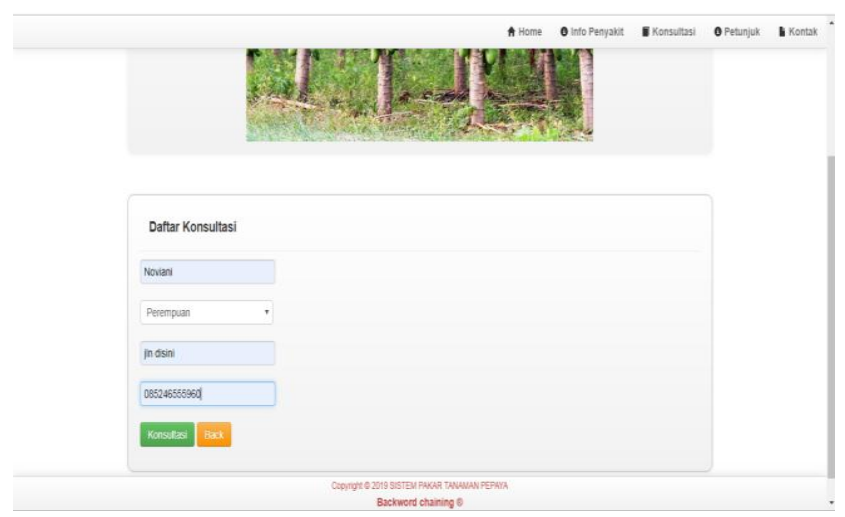

Gambar 6. Halaman Konsultasi

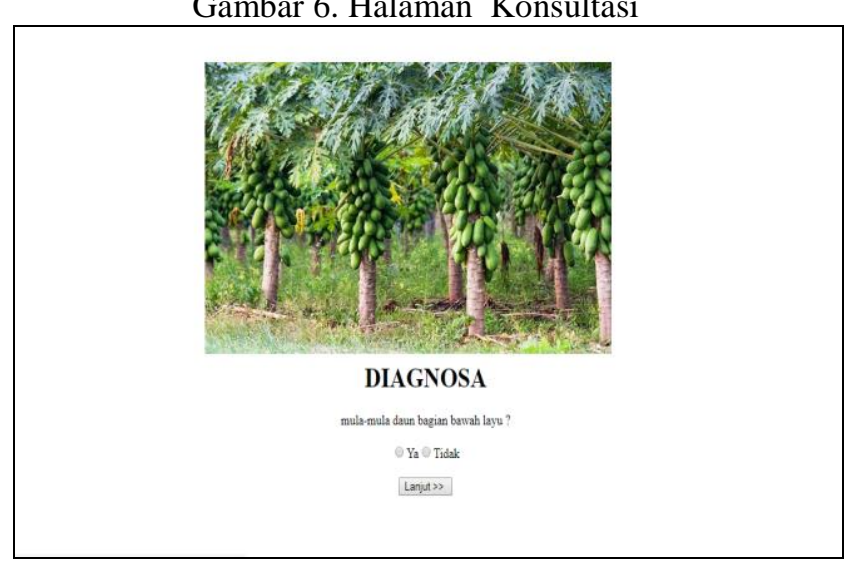

Gambar 7. Halaman Konsultasi

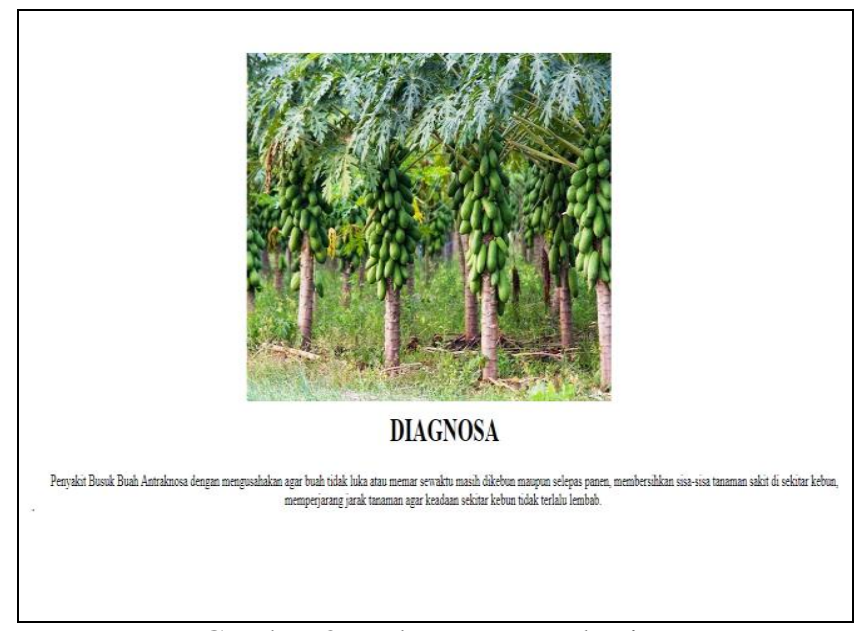

Gambar 8. Halaman Konsultasi

\section{4) Halaman Petunjuk}

Pada menu disini dijelaskan mengenai cara penggunaan aplikasi. 


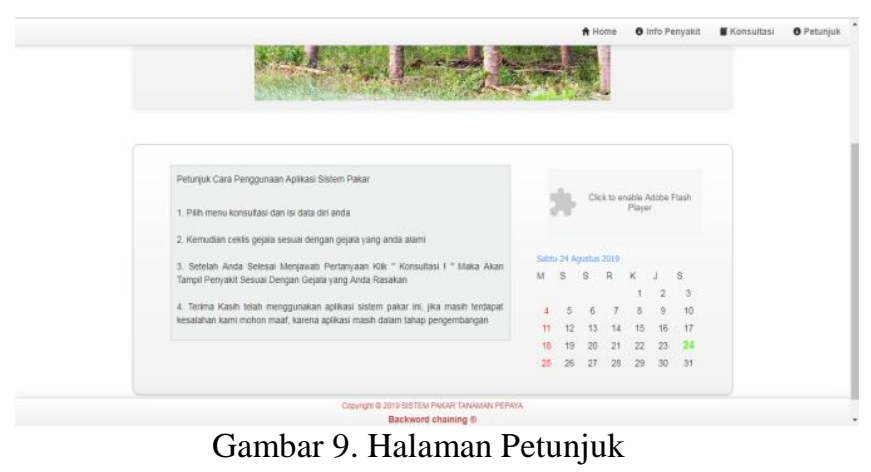

5) Login Administrator

Tampilan halaman login merupakan tampilan awal dari halaman admin. Pada menu ini admin dapat melakukan login untuk masuk kehalaman Kelola, Informasi, Hasil Konsultasi, Tentang Kami, Logout.

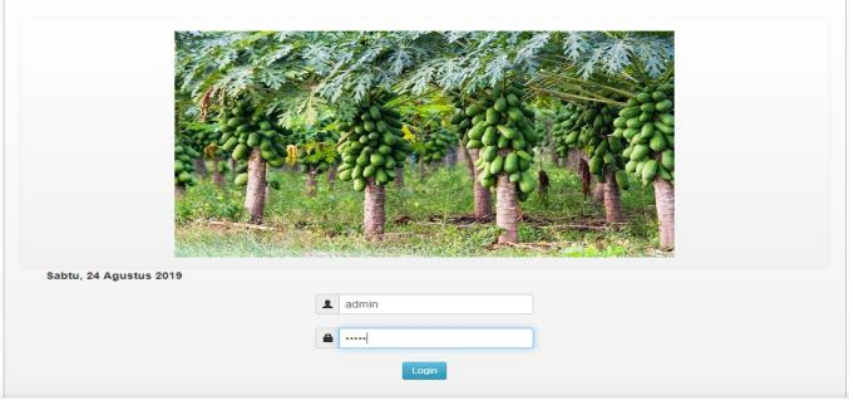

Gambar 10. Halaman Login

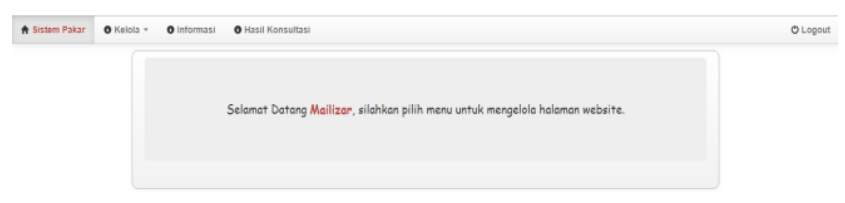

Gambar 11. Halaman Pengaturan

6) Data Kelola

Pada menu ini terdapat data kelola dimana didalam terdapat data gejala dan data penyakit dimana. Didalam tabel data gejala ada no, kode gejala nama gejala dan data penyakit.

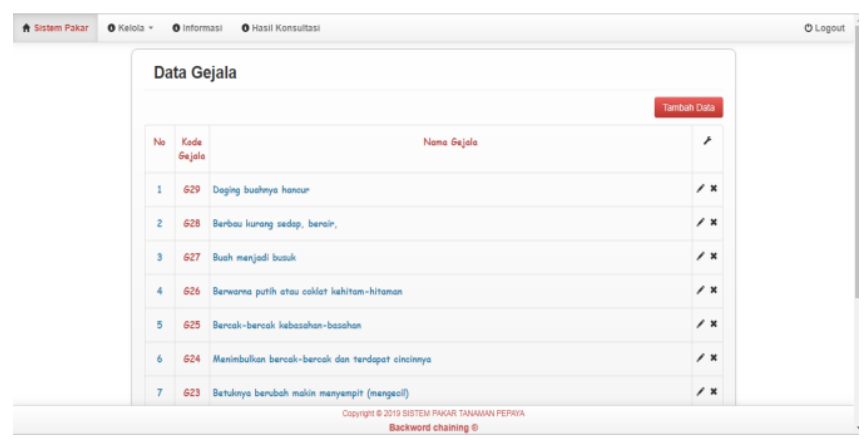

Gambar 12. Halaman Gejala
Data penyakit dan dimana didalam tabel data penyakit ada no, kode penyakit, solusi.

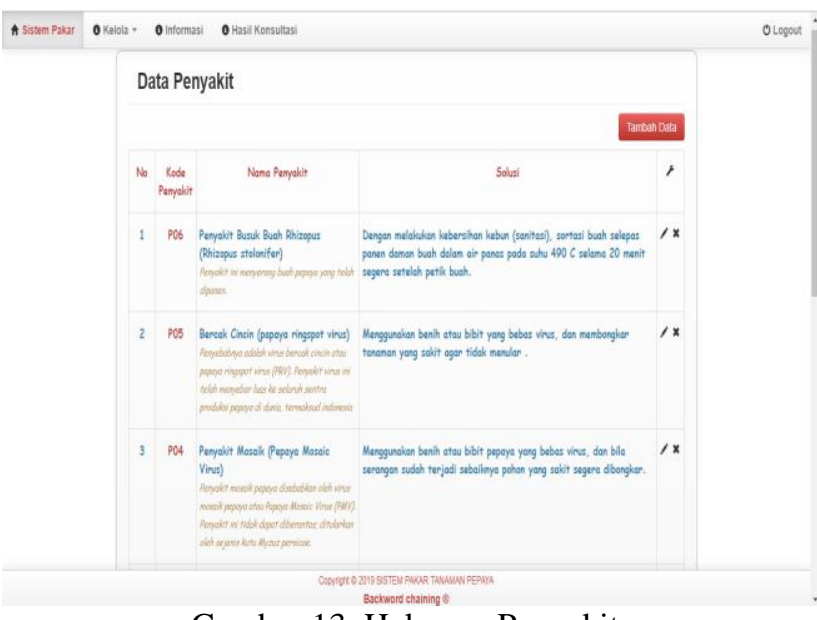

Gambar 13. Halaman Penyakit

\section{7) Menu Data Informasi}

Pada menu ini terdapat data informasi dimana dalam tabel data tersebut ada no, judul, isi, tanggal dan keterangan.

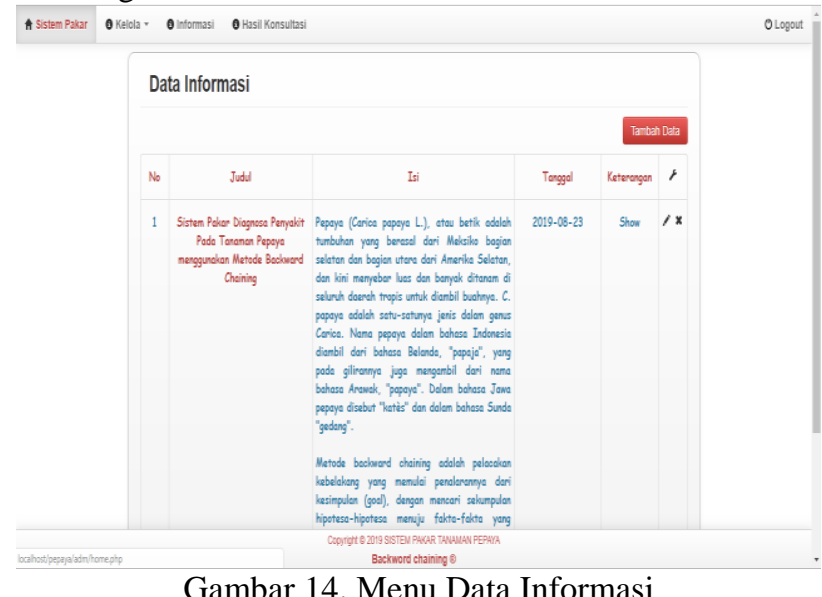

8) Halaman Hasil Konsultasi

Pada menu ini terdapat hasil konsultasi dimana didalam memenuhi syarat ketentuan metode yang digunakan maka muncul nama gejala dan nama gejala, didalam.

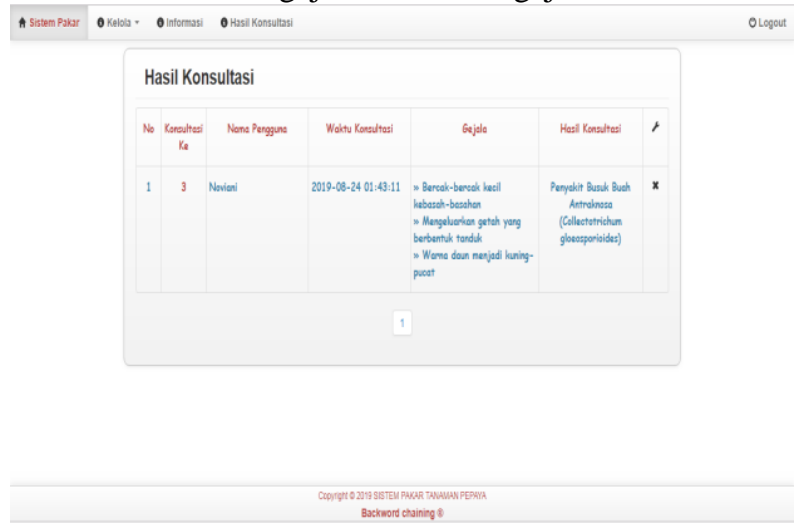

Gambar 15. Halaman Hasil Konsultasi 


\section{Pembahasan}

Hasil pengujian dilakukan dengan menggunakan metode Black Box Testing, merupakan metode testing pengujian yang dilakukan hanya mengamati hasil eksekusi melalui data uji dan memeriksa fungsional dari perangkat lunak.

Tabel 4. Pengujian black box

\begin{tabular}{|c|c|c|}
\hline Input & Output & $\begin{array}{c}\text { Hasil } \\
\text { Pengujian }\end{array}$ \\
\hline Klik menu Home & $\begin{array}{l}\text { Menampilkan halaman } \\
\text { utama }\end{array}$ & Berhasil \\
\hline $\begin{array}{l}\text { Klik menu data } \\
\text { info penyakit }\end{array}$ & $\begin{array}{l}\text { Menampilkan halaman } \\
\text { data info penyakit }\end{array}$ & Berhasil \\
\hline $\begin{array}{l}\text { Klik menu data } \\
\text { konsultasi }\end{array}$ & $\begin{array}{l}\text { Menampilkan halaman } \\
\text { data konsultasi }\end{array}$ & Berhasil \\
\hline $\begin{array}{l}\text { Klik tombol } \\
\text { menu petunjuk }\end{array}$ & $\begin{array}{l}\text { Menampilkan halaman } \\
\text { menu petunjuk }\end{array}$ & Berhasil \\
\hline $\begin{array}{l}\text { Klik tombol login } \\
\text { administrator }\end{array}$ & $\begin{array}{l}\text { Menampilkan halaman } \\
\text { login admin }\end{array}$ & Berhasil \\
\hline $\begin{array}{l}\text { Klik menu data } \\
\text { kelola }\end{array}$ & $\begin{array}{l}\text { Menampilkan halaman } \\
\text { data kelola }\end{array}$ & Berhasil \\
\hline $\begin{array}{l}\text { Klik menu data } \\
\text { informasi }\end{array}$ & $\begin{array}{l}\text { Menampilkan halaman } \\
\text { data informasi }\end{array}$ & Berhasil \\
\hline $\begin{array}{l}\text { Klik menu data } \\
\text { hasil konsultasi }\end{array}$ & $\begin{array}{l}\text { Menampilkan halaman } \\
\text { data hasil konsultasi }\end{array}$ & Berhasil \\
\hline
\end{tabular}

\section{KESIMPULAN}

Telah berhasil dibuat sebuah aplikasi Sistem Pakar Diagnosa Penyakit pada tanaman papaya berbasis web untuk membantu umum dan petani dalam mengidentifikasi penyakit yang disebabkan gejala-gejala yang diberikan.Sistem pakar yang dibangun dapat bermanfaat bagi masyarakat umum dan petani untuk mengetahui informasi tentang penyakit pepaya.

Pembuatan aplikasi ini masih dapat dikembangkan seiring dengan berkembangnya spesifikasi kebutuhan pengguna dan membuat tampilan aplikasi lebih menarik lagi. Pembuatan sistem ini harapan saya bisa bermanfaat bagi para petani pepaya dan masyarakat umum dalam kehidupan sehari hari.

\section{DAFTAR PUSTAKA}

A.Tarigan, F. (2014). Sistem Pakar Untuk Mendiagnosa Penyakit Ginjal Dengan Metode Backward chaining. Jurnal Times .

Destiningrum, M., \& Adrian, Q. J. (2017). Sistem Informasi Prnjadwalan Dokter Berbasis Web Dengan Menggunakan Framework Codeignter (Studi Kasus: Rumah Sakit Yukum Medical Center). Jurnal Teknoinfo.
Efandy, M. Y., Alfeno, S., \& Christianto, A. (2016). Penerapan Backward Chaining Sebagai Model Criminal Investigation Expert System (CRIES) Untuk Menangani Kasus Pembunuhan. Jurnal Global.

Februariyanti, H., \& Zuliarso, E. (2012). Rancang Bangun Sistem Perpustakaan Untuk Jurnal Elektronik. Jurnal Teknologi Informasi.

Firman, A., Wowor, H. F., \& Najoan, X. (2016). Sistem Informasi Perpustakaan Online Berbasis Web. Jurnal Elektro dan Komputer.

Fuljana, M. (2017). Sistem pakar Diagnosa Penyakit Tanaman Cabai Menggunakan Metode Forward Chaining Berbasis Android.

Honggowibowo. (2009). Sistem Pakar Diagnosa Penyakit Tanaman Padi Berbasis Web Dengan Forward Dan Backward Chaining". Jurusan Teknik Informatika, Sekolah Tinggi Teknologi Adisutjipto. Jurnal Teknik Informatika, Vol. 7, No. 3: 187-194.

Kustiyahningsih. (2011). Pemrograman Basis Data Berbasis WEB Menggunakan PHP dan Mysql. Yogyakarta: Graha Ilmu.

Maryati, S. E. (2005). Pengaruh Sarcotesta dan Pengeringan Benih serta Perlakuan Pendahuluan terhadap Viabilitas dan Dormansi Benih Pepaya (Carica papaya L.). Bul. Agron, (33) (2) 23-30.

Maulina, B. A., \& S, H. D. (2016). Sistem Pakar Diagnosis Hama dan Penyakit Tanaman Kacang Tanah Berbasis Desktop Dengan Backward Chaining. Jurnal Informatika.

Mutia, A., Triyanto, D., \& Iihamsyah. (n.d.). Sistem Pakar Untuk Mendiagnosa Penyakit Pada Sistem Pernafasan Menggunakan Metode Forward Chaining dan Backward chaining.

Pratitis, A. N. (2010). Sistem Pakar Diagnosa Penyakit dan Hama Pada Tanaman Pepaya California didusun Kethitang-Rawalo. Jurnal Telematika.

Mutia, A., Triyanto, D., \& Iihamsyah. (n.d.). Sistem Pakar Untuk Mendiagnosa Penyakit Pada Sistem Pernafasan Menggunakan Metode Forward Chaining dan Backward chaining.

Pratiwi, A. E. (2018). Sistem Diagnosa Penyakit Pada Tanaman Cabai Merah Dengan Metode Backward Chaining (Studi Kasus: Petani Cabai Merah Desa Grobongan Kabupaten Madium). Journal of Applied Informatics.

Rukmana, R. (1995). Pepaya Budidaya dan Pasca Panen. Yogyakarta: Kanisius.

Simarmata, J. (Yogyakarta). Perancangan Basis Data . 2010: CV. Andi Ofsset.

Turban, E. (2015). Decision Support System and Intellegent System. Yogyakarta. 